\title{
PONTHIEVA HERMILIAE, A NEW SPECIES OF ORCHIDACEAE IN THE CORDILLERA YANACHAGA (OXAPAMPA, PASCO, PERU)
}

\author{
Luis Valenzuela Gamarra
}

\author{
Missouri Botanical Garden. Prolongación Bolognesi Mz. E Lote 6, Oxapampa-Pasco, Perú \\ luis_gin@yahoo.es
}

\begin{abstract}
A new species of Ponthieva was found in the mountains of Yanachaga Chemillén, on a pre-montane forest at $1400 \mathrm{~m}$ in the central jungle of Peru. It is similar to P. pilosissima, but can be distinguished by the presence of a callus on the lip and by the color of the petals, which are boldly veined in P. pilosissima and inconspicuously striped in P. hermiliae.
\end{abstract}

Key words: Orchidaceae, Orchidoideae, Ponthieva, new species, Peru, Yanachaga

The Orchidaceae family amazes most researchers because of its great diversity, with more than 28,000 species worldwide (Govaerts et al. 2012). Just below 2,900 have been reported to grow in Peru (Zelenko \& Bermudez 2009), however, considering the vastness of the territory and diversity in complex ecosystems, those numbers will probably increase. The Cordillera Yanachaga Chemillén, located in the Oxapampa province, is a region that has remained unexplored and is likely to host orchid species not yet known to science.

Globally there are a little over 3600 species of Orchidoideae (Bateman et al. 2003), which mainly share terrestrial habits. Members of the subfamily are characterized by a single fertile upright anther with sectile pollinia. The genus Ponthieva was named in honor of Henri Ponthieu, a French merchant who was sending plant collections from the West Indies to Mr. Joseph Banks in 1778. The genus is distributed from the southern United States, Mexico, Caribbean to southern Brazil, Colombia, Ecuador, Peru and Bolivia. They are mainly terrestrial plants but occasionally grow epiphytically. They have thickened fibrous roots, covered by long soft hairs and a stem that develops from the rhizomes. The flowers are arranged on a cluster inflorescences, with bracteate peduncles. The dorsal sepal is apically fused to the petals, which may or may not be fused to the sides of the column (Dodson \& Escobar 2003).

Ponthieva hermiliae L.Valenzuela, sp. nov.

Type: Peru. Pasco, Oxapampa, Yanachaga Chemillén
National Park, 1400 m. 10²4’36”S 075¹9'48”'W. L. Valenzuela 20064, M. I. Villalba, J. Mateo \& R. Rivera (holotype, HOXA). Fig. 1, 2A-C.

Species Ponthievae pilossimae (Sengh.) Dodson similis, petalibus distincte callosis in parte basali dilute brunneo striato-maculatis, labello basaliter exauriculato, calli margo proximalis rotundato non exciso praecipue recedit.

Epiphytic herb, up to $46 \mathrm{~cm}$ tall including the inflorescence. Leaves spathulate-elliptic, flexuous, 24$26 \times 2.0-2.5 \mathrm{~cm}$, covered by clavate, glandular hairs 1 $\mathrm{mm}$ long. Inflorescence a successively many-flowered raceme with 5-7 flowers opened at once. Floral bracts $1.5 \mathrm{~cm}$ long, hairy. Pedicellate ovary covered with trichomes, $3 \mathrm{~cm}$ long including the pedicel. Sepals lanceolate, the lateral falcate-lanceolate, covered externally with glandular trichomes, yellowish green marked with brown at the insertion point, 1.0-2.0 $\times 0.4$ $0.5 \mathrm{~cm}$. Petals oblong-lanceolate, $1.9-2.0 \times 0.25-0.30$ $\mathrm{cm}$, whitish green with a faint, parallel, light brown venation, provided with an ellipsoid callus located in the lower quarter. Lip yellowish-green to greenish-white, 6 $\mathrm{mm}$ long, lanceolate-triangular, slightly concave in the proximal half and at the rear, with a 6-toothed callus arranged horizontally in front of the basal cavity. Anther cap ovate-triangular, cucullate, verrucose, dark green. Pollinia 4 in two pairs, clavate, $1 \mathrm{~mm}$ long, supported by a flexible elongate stipe.

Distribution and ECOlOGY: Epiphyte found on the eastern flank of the Cordillera Yanachaga Chemillén, where it is apparently restricted to constantly foggy, 

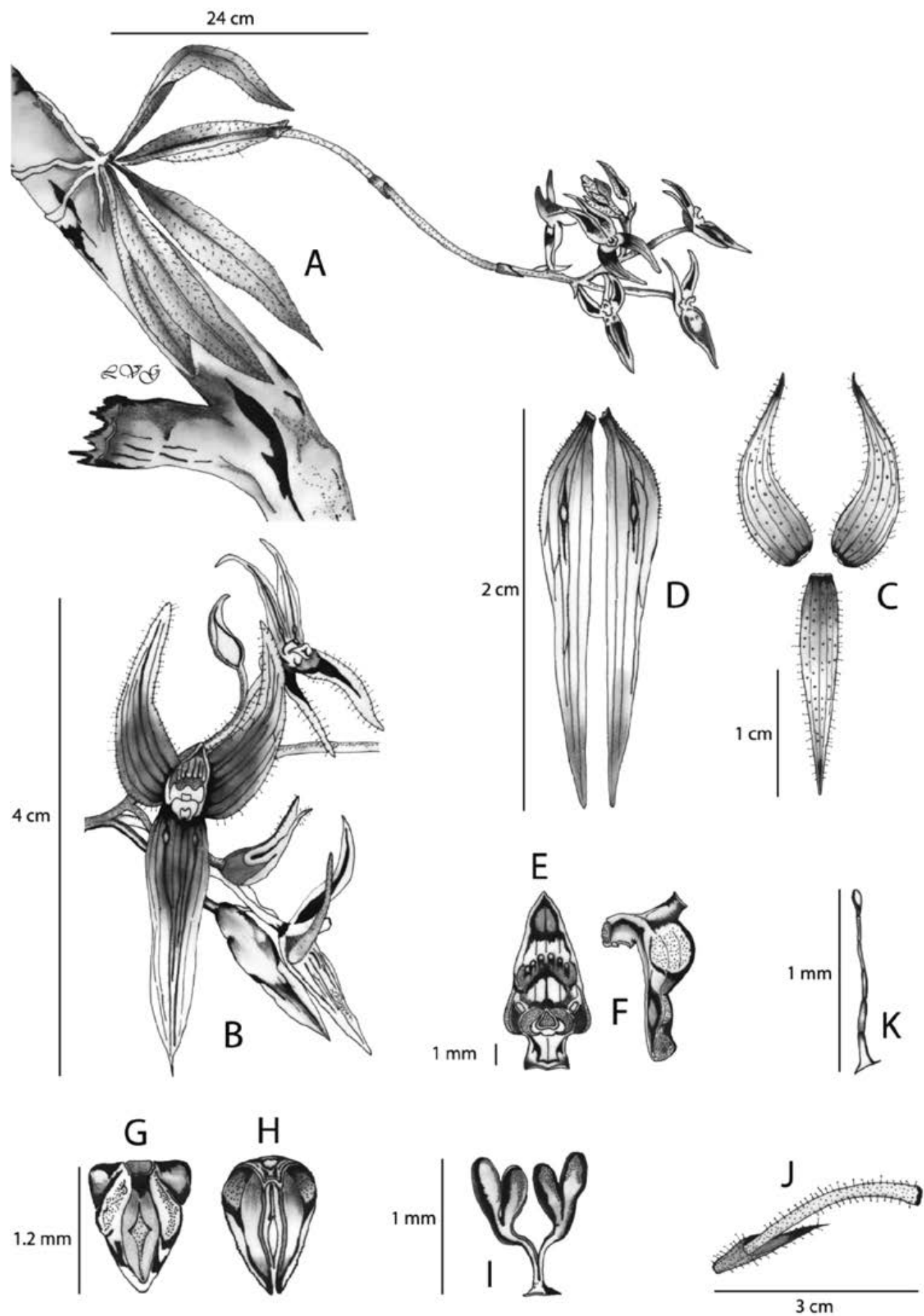

Figure 1. Ponthieva hermiliae L.Valenzuela. A. Habit. B.Flower and detail of the inflorescence. C. Sepals. D. Petals. E. Column and lip, frontal view. F. Column and lip, lateral view. G. Anther cap, ventral view. H. Anther cap, dorsal view. I. pollinarium. J. Floral bract and pedicel. K. Hair. Drawn by the author from the holotype. 

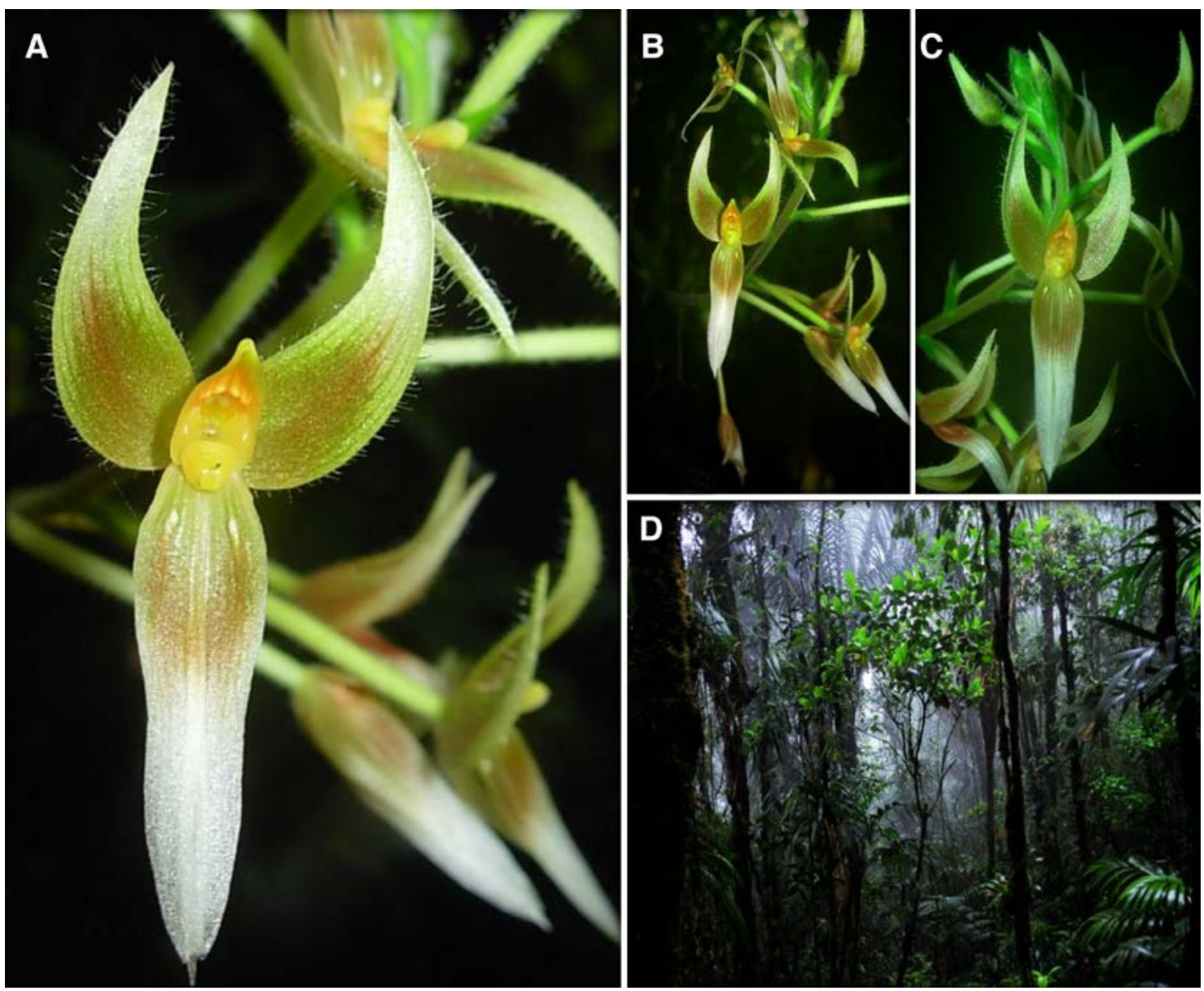

Figure 2. Ponthieva hermiliae. A. Flower. B-C. Details of the inflorescence. D. Habitat. Photographs by the author.

premontane forest (fig. 2D). The plants are growing mainly on the root stem of tree ferns (Cyathea spp).

Eponymy: The name honors Gina Hermila Gamarra Muñiz, the author's mother.

Ponthieva hermiliae is similar to $P$. pilosissima (Senghas) Dodson, but differs in exauriculate base of the lip (vs. with distinct retrorese lobes), the shape of the callus on the lip (rounded vs. excise), and the petals distinctly callose at the base, faintly striped with light brown (vs. obscurely callose, boldly striped with redish brown). Furthermore, the sepals of $P$. hermiliae are subsimilaar in size, whereas in P. pilosissima the dorsal sepal is much smaller (Senghas 1989).

ACKNOWLEDGEMENTS. The author wishes to thank Missouri Botanical Garden for the economic contribution and allowing scientific research in Peru, where many new taxa are discovered and described to science. To Stig Dalström for help with the translation; to Rodolfo Vásquez M., Rocío del Pilar Rojas G. and María Isabel Villalba V. for their additions to the manuscript.

\section{Literature Cited}

Bateman, R. M., P. M. Hollingsworth, J. Preston, L. YiBo, A. M. Pridgeon \& M. W. Chase. 2003. Molecular phylogenetics and evolution of Orchidinae and selected Habenariinae (Orchidaceae). Bot. J. Linn. Soc. 142: $1-40$.

Dodson C. H. 1996. Nuevas Especies y Combinaciones de orquídeas ecuatorianas -4 / New orchid species and Combination from Ecuador - 4. Orquideología 20 (1): 90-111.

Dodson, C. H. \& R. Escobar. 2003. Orquídeas Nativas del Ecuador. Volumen IV. Oncidium-Restrepiopsis. Editorial Colina, Medellín.

Govaerts, R., J. Pfahl, M.A. Campacci, D. Holland Baptista, 
H. Tigges, J. Shaw, P. Cribb, A. George, K. Kreuz \& J. Wood. 2012. World Checklist of Orchidaceae. The Board of Trustees of the Royal Botanic Gardens, Kew. Senghas, K. 1989. Die Gattung Chranichis, mit einer neuen Art, Chranichis pilosissima, aus Ekuador. Orchidee
(Hamburg) 40 (2): 44-51.

The Angiosperm Phylogeny Group (APG III). 2009. Botanical Journal of the Linnean Society (161): 105-121. Zelenko H. \& P. Bermúdez. 1999). Orchids: species of Peru. ZAI Publications. Quito, Ecuador. 